\title{
UNCLEAR ORIGIN OF THE NEW LOCALITY OF CHAMAECYTISUS ALBUS ROTHM. (HACQ.) IN POLAND: A CASE OF STUDY
}

\author{
AloJZY PRZEMYSKI ${ }^{1}$, BARTOSZ PIWOWARSKI $^{2}$ \\ ${ }^{1}$ Departament of Botany, Institute of Biology, J. Kochanowski University \\ Świętokrzyska 15, 25-406 Kielce, Poland \\ alojzy.przemyski@ujk.kielce.pl \\ 2 Department of Plant Taxonomy and Phytogeography, \\ Institute of Botany, Jagiellonian University \\ Kopernika 27, 31-501 Kraków, Poland
}

(Received: March 20, 2009. Accepted: July 22, 2009)

\begin{abstract}
Chamaecytisus albus (Hacq.) Rothm. is an extremely rare species, which is inserted in many European red lists and red books. Its continuous range covers the south-eastern part of Europe. That species grows in intensely insolated and calcareous habitats of xerothermic grasslands. Only one station of White Broom had been known in the valley of the Bug river, near Hrubieszów, but in 2007 a new one was discovered near Jędrzejów. That station is located the farthest in the north and the west in Europe and it is completely detached from the continuous range.
\end{abstract}

KEY WORDS: Chamecytisus albus, new station, Jedrzejow, xerothermic grassland.

\section{INTRODUCTION}

White Broom Chamaecytisus albus (Hacq.) Rothm. (syn. Cytisus albus Hacq.) belongs to the Fabaceae family (Papilionaceae), the Faboideae subfamily. It is included in the arborescent chamaephytes group. This is an extremely rare species in the whole of Europe. It is similarly in Poland, where it has a clearly extrazonal character. Therefor the Broom is taken under national strict protection and it is also placed in the Polish Red List (Zarzycki and Szeląg 2006) as a rare - potentially endangered - category $\mathrm{R}$, whereas in the Polish Red Book it is considered as an endangered species - EN (Fijałkowski 2001).

The species covers a south-eastern part of Europe, the Pannonian region and partly the Mediterranean area (the Balcans, Grace, Romania, Bulgaria, Albania, Hungary, the Czech Republic, Slovakia, Ukraine, the European part of Turkey) - Fig. 1.

The species is not frequent within the borders of its range and the more in the north it becomes extremely rare (Hegi 1963; Browicz and Gostyńska-Jakuszewska 1966). That plant is attached to xerothermic shrubs habitats on loess and calcareous soils, where it grows on steep slopes with southern exposures. Gajewski (1937) considers White Broom as a forest species within its continuous range of distribution, whereas in Polish stations it appears on entirely exposed or with small overshading places.
White Broom has been known from only one station in Poland; it was first discovered in 1953 (Fijałkowski 1954) in Lubelszczyzna, near Hrubieszów (Fig. 2). It appears there on steep loess slopes in the valley of the Bug river, with SE, E, NE exposures. Fijałkowski (1957), during following researches, distinguished the Prunetum fruticosae var. Chamaecytisus albus assocation, where the discussed species covers $60 \%$ of the studied phytocoenosis patch and dominates over Brachypodium pinnatum (20\%), Cerasus fruticosa B (10\%) and Filipendula vulgaris (10\%). Unfortunately, nowadays that station is less numerous and mean cover decreased to $10 \%$ (Fijałkowski 2001). That author recognizes "a fence of the area and a fire of grassland" as reasons of decreasing the number of population. The station of Ch. albus in the Czech Republic is one of the nearest location in the neighborhood of Poland (Kubát 2002). The aim of this study is to present the new station of Ch. albus in Poland as well as discuss the possible origin of the local population.

\section{METHODS}

Blooming Ch. albus individuals have been counted in July 2007 and 2008. Well separated clumps (groups of above groundshoots) were considered as individuals. Phytosociological records were done in 2007 following the $\mathrm{Zu}$ - 


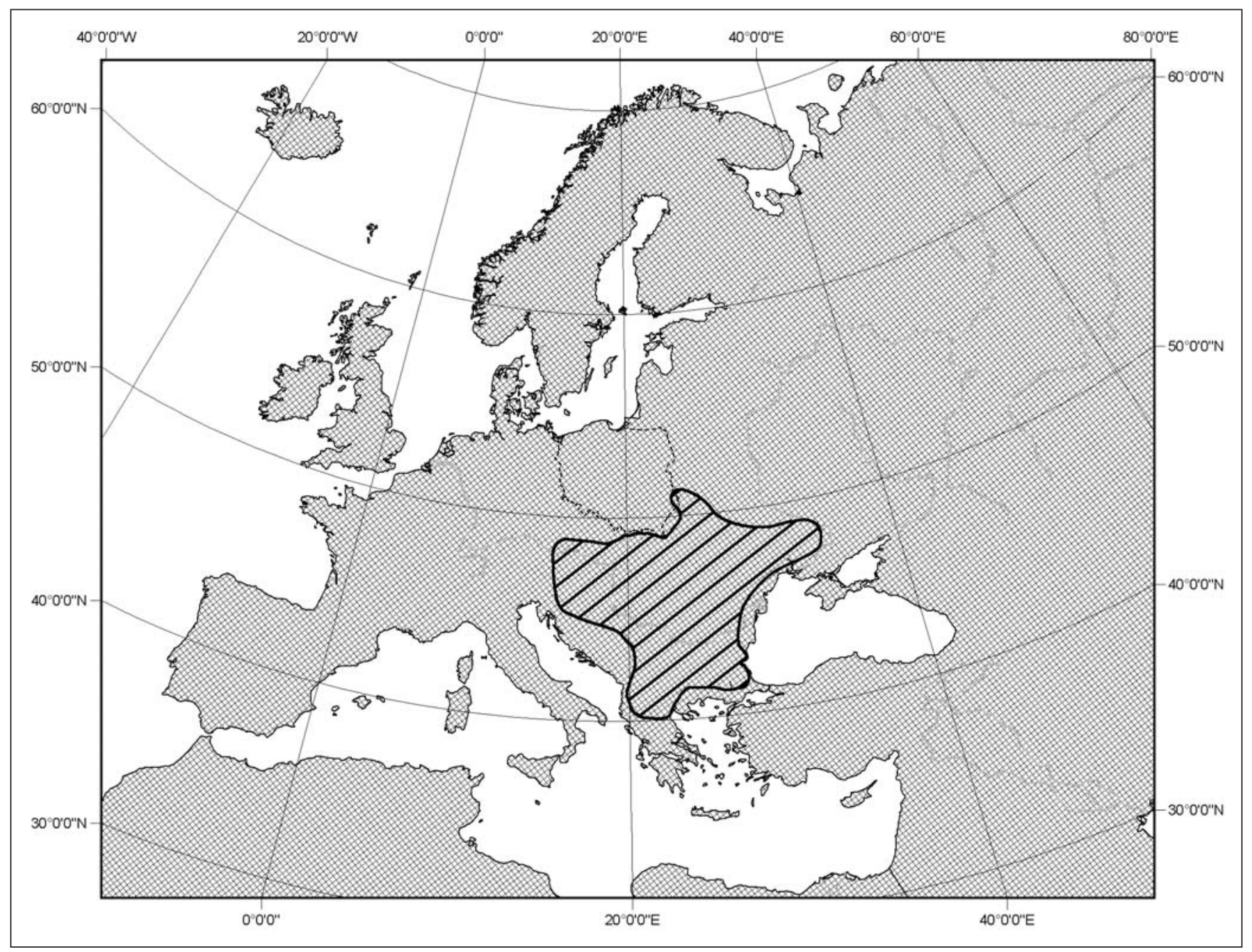

Fig. 1. Distribution of Chamaecytisus albus Rothm. (Hacq.) in Europe.

rich-Montpellier School of Phytosociology (Dzwonko 2007). Phytosociological nomenclature, species characteristic for a class (Ch. Cl.), order (Ch. O.) and association (Ch. Ass.) was based on Matuszkiewicz (2005). Names of vascular plant species are given according to Mirek et al. (2002).

\section{RESULTS}

\section{The new station site}

In June 2007 the new station of Chamaecytisus albus was found in the vicinity of Jędrzejów. It is located near the local road between "Eysaków Pod Lasem" spot and Diament and about $4 \mathrm{~km} \mathrm{~S}$ away from Jędrzejów (Fig. 3). According to physiographical division of Poland the station is located in Jędrzejów Plateau mesoregion and Niecka Nidziańska macroregion (Kondracki 2002). In accordance with the ATPOL division the studied area is situated in EF 0220 square $(2.5 \times 2.5 \mathrm{~km})$ (Zając 1978).

\section{Neighboring plants}

The species grows on the roadside and xerothermic oakwood Potentillo albae-Quercetum, which reveals a tendency to develop into thermophilous oak-hornbeam woods Tilio cordatae-Carpinetum betuli. The population develops on a rather small area with dimension of about $3 \times 40 \mathrm{~m}$.
The shoreland of oakwood and the road has a character of xerothermic grassland, which is deformed by developing shrubs and trees as well as because of the occurrence of synanthropic species. The phytocoenosis has a two-layered structure. The shrub layer is dominated by roses Rosa cani$n a, R$. dumalis, $R$. sherardii, and then by Rhamnus cathartica, Prunus spinosa, Crataegus rhipidophylla. The herb undergrowth, which is intensely shaded by developing shrubs, is created by species typical for the Festuco-Brometea class, and then by species characteristic of Trifolio-Geranietea sanguinei. There are numerous species from the synanthropic communities Stellarietea mediae and Artemisietea vulgaris and forest species from the Querco-Fagetea class. Probably, the stability of the phytocoenosis is mantained because of sporadic cutting out the shrubs in a road lane. The species composition of the given phytocoenosis is presented in the relevé no. 1.

Relevé 1. 30.07.2008; the roadside passing the forest: B-20\%: Rosa canina 2; Crataegus rhipidophylla 1; Rhamnus cathartica 1, Fraxinus excelsior + ; Prunus spinosa $+;$ Pyrus communis +; Rosa sherardii +; Tilia cordata +. C-90\%: Ch. Cl. Trifolio-Geranietea sanguinei: Coronilla varia 2; Medicago falcata 1; Agrimonia procera +; Astragalus glycyphyllos +; Campanula rapunculoides +; Galium verum +; Melampyrum nemorosum +; Viola hirta + . Ch. Cl. Molinio-Arrhenatheretea: Lathyrus palustris 1; Achillea mille- 

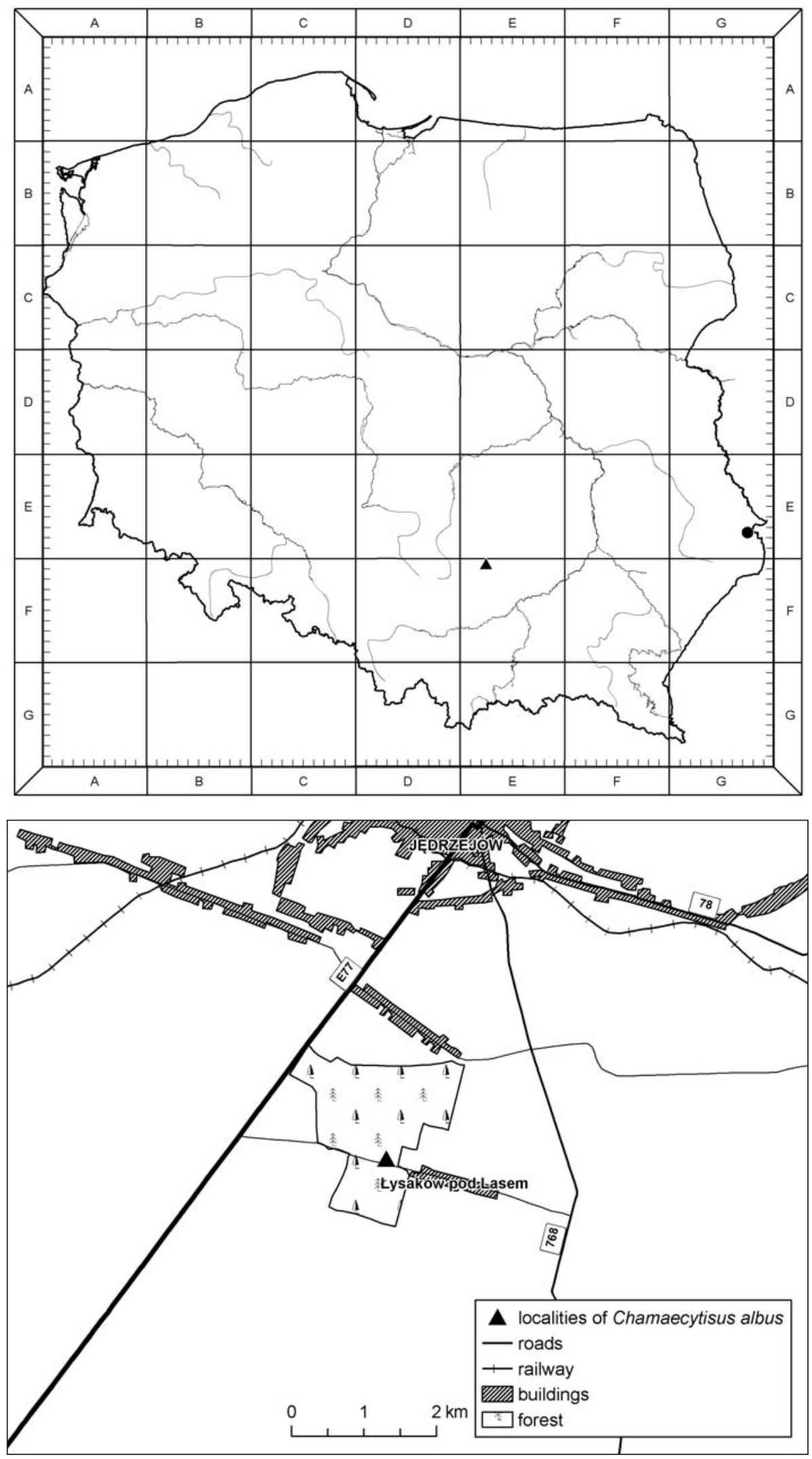

Fig. 2. Distribution of Chamaecytisus albus Rothm. (Hacq.) in Poland ( - known station near Hrubieszów; $\boldsymbol{\Delta}$ - new station near Jędrzejów).
Fig. 3. Detailed location of new station of Chamaecytisus albus Rothm. (Hacq.) on the Jędrzejów Plateau. folium +; Dactylis glomerata +; Daucus carota +; Galium mollugo +; Heracleum sphondylium +; Tragopogon pratensis +; Vicia cracca +. Ch. Cl. Querco-Fagetea: Fraxinus excelsior 1; Acer platanoides +; Cerasus avium +; Euonymus verrucosa + ; Lathyrus niger + ; Lathyrus vernus + ; Primula veris + . Ch. Cl. Festuco-Brometea: Brachypodium pinnatum 2; Euphorbia cyparissias 1; Ajuga genevensis +; Allium oleraceum +; Festuca rupicola + . Others: Rosa ca- nina 3; Prunus spinosa 2; Rubus caesius 2; Agrimonia eupatoria 1; Carex tomentosa 1; Chamaecytisus albus 1; Clinopodium vulgare 1; Fragaria vesca 1; Poa angustifolia 1; Rhamnus cathartica 1; Veronica chamaedrys 1; Carex spicata +; Cerinthe minor +; Convolvulus arvensis +; Festuca ovina +; Geum urbanum +; Hypericum perforatum + ; Medicago $x$ varia + ; Melandrium album + ; Melilotus officinalis +; Myosotis arvensis +; Pimpinella saxifraga +; Plantago 
media +; Potentilla reptans +; Quercus petraea +; Quercus robur + ; Sanguisorba minor + ; Torilis japonica + . $\mathbf{D}<\mathbf{1 \%}$ : Thuidium abietinum + .

The searches of Chamaecytisus albus were also conducted in the area of xerothermic oakwood, which directly borders on its station. Unfortunately, they did not give expected results. Nevertheless, there was also a relevé made, because it could enrich the knowledge about the vegetation in that area and that would be helpful in forming an adequate way of active protection of the species in that station. The species composition of xerothermic oakwood is presented in the relevé no. 2.

Relevé 2. 30.07.2008; xerothermic oakwood Potentillo albae-Quercetum with a large share of Ash Fraxinus excelsior: A1-70\%: Quercus robur 4; Fraxinus excelsior 1; Acer pseudoplatanus +; Larix decidua +. A2-10\%: Acer pseudoplatanus +; Robinia pseudoacacia +. B-20\%: Crataegus rhipidophylla 1; Prunus spinosa 1; Acer pseudoplatanus +; Cerasus avium +; Frangula alnus +; Quercus petraea +; Quercus robur +. C-80\%: Ch. Ass. Potentillo albae-Quercetum, Ch. O. Quercetalia pubescenti-petreae: Lathyrus niger 2; Campanula persicifolia $+;$ Hypericum montanum +; Melittis melisophyllum +; Potentilla alba +; Pulmonaria angustifolia +. Ch. Cl. Querco-Fagetea: Fraxinus excelsior 1; Lathyrus vernus 1; Viola reichenbachiana 1; Acer platanoides +; Acer pseudoplatanus +; Brachypodium sylvaticum +; Cerasus avium +; Festuca gigantea +; Poa nemoralis +; Primula veris + ; Sanicula europaea + ; Ulmus minor +. Ch. Cl. Molinio-Arrhenatheretea: Betonica officinalis 1; Serratula tinctoria 1; Alchemilla monticola +; Dactylis glomerata +; Festuca rubra +; Lathyrus pratensis +; Trollius europaeus +; Vicia cracca +. Ch. Cl. TrifolioGeranietea sanguinei: Melampyrum nemorosum 2; Viola hirta 1; Agrimonia eupatoria +; Astragalus glycyphyllos +; Clinopodium vulgare + ; Galium verum + ; Peucedanum cervaria + . Ch. Cl. Festuco-Brometea: Brachypodium pinnatum 3; Allium oleraceum +; Campanula glomerata +; Euphorbia cyparissias +. Others: Carex montana 2; Avenula planiculmis 1; Cruciata glabra 1; Fragaria vesca 1; Prunus spinosa 1; Quercus petraea 1; Quercus robur 1; Agrostis capillaris +; Ajuga reptans +; Carex flacca +; Carex pallescens +; Euphorbia angulata +; Geum urbanum +; Hypericum perforatum +; Juniperus communis +; Luzula pilosa + ; Poa angustifolia + ; Pyrus communis + ; Rhamnus cathartica + ; Rosa canina + ; Rosa gallica + ; Solidago virgaurea +; Veronica chamaedrys +; Veronica officinalis +; Vicia tetrasperma +. D-10\%: Atrichum undulatum 1; Plagiomnium affine 1; Brachytheciastrum velutinum + ; Fissidens sp. +; Hypnum cupressiforme +; Plagiomnium cuspidatum +; Polytrichastrum formosum +; Pseudoscleropodium purum +; Rhytidiadelphus squarrosus + .

\section{Population size}

The observations which were made in 2007 and 2008 showed that the whole local population of Ch. albus consisted of 40 clumps. The condition of the particular clumps was good, even though the population was not so numerous and only a few of young juvenile were noted. The highest individual stems reached $60 \mathrm{~cm}$ height. In each clump a great majority of branches richly bloomed and fru- ited. The seeds were well developed and there were, on average, 4-5 diasporas in a pod.

\section{DISCUSSION}

\section{Population origin}

The origin of that station is a fundamental issue. The road, near which the discussing species grows, has a local character and there is a low motor traffic, so it is unlikely that Ch. albus was dragged there by lorries e.g. from Ukraine. The oak wood, which neighbours with the station, was planted and it reveals in the distribution of trees rows and it is also confirmed by foresters. Could there have been a glade previously in that area? It seems to be rather unlikely. There could be a rural pasture in the past, because in this area a shallow rendzina forms and it is not a favourable cultivation condition. Many of that kind of glades were in the local forests, especially on its verges, and they were pastured by the resident community. The old maps from 1938 and the maps of Radom's guberniya from 1839 (www.mapywig.org) (they are, admittedly, not so precise) present the forest complexes in that area. However, it does not prejudge the question of the local glades presence, especially in the vicinity of settlements.

This species is also cultivated and it is distributed by ornamental bushes or flower seedbeds in eastern Europe as well as in Poland. In spite of several dozen years' field researches it has not been found in adjacent cultivations in the Małopolska Upland. There is still the possibility that White Bloom was planted there because of the presence of a small tree shrine, which is placed on an old pedunculate oak (Quercus robur); that old tree with a branchy treetop can be also a proof for former existence of xerothermic oakwood or a small glade.

Nowadays, it is hard to give an unequivocal answer about the history of that station.

The discussed station of Ch. albus maybe has a natural character. That species could come with migration of another thermophilic species from the Podolia and Pannonic refugia.

The linking station from the Hrubieszów precincts by the Bug river confirms that conjectures. Shallow rendzina and the presence of open grades were attractive habitats for its vegetation.

Moreover, other thermophilic species, which grow nearby also prove the hypothesis related to the naturalness of the station e.g. Cypripedium calceolus, Brachypodium pinnatum, Peucedanum cervaria, Poa angustifolia, Primula veris, Rosa gallica, Tanacetum corymbosum.

\section{CONCLUSION}

The newly-discovered station of Chamaecytisus albus changes the range limit of its distribution, and moves it significantly more to the north and west of Europe. Its population is not numerous and the habitat (the edge of the forest and the road) is not a stable coenosis.

In connection with this an active protection should be introduced on that station, since the habitat conditions, in which the species develops, undoubtedly need man's interference. First of all, the station should be denuded by cut- 
ting out the luxuriant brushwood of trees and shrubs. The neighborhood of the rood is a significant stress-inducing factor for the species, that is why it is important to create new possibilities of its expansion. Cutting out several ares of forest nearby the station seems to be a good solution as well as holding an active protection, which could lead to formation of xerothermic grasslands or very light xerothermic oakwoods. That actions could cause a transfer of the species from the threatened edge of the road to a new favourable habitat. Such practices could augment the chances of survival of the species in that station. A regular Environment Monitoring is also essential for the existence of that station.

The determination of the species origin is an extremely important matter. Therefore, further researches should be continued, mainly in the molecular field and thanks to them it will be possible to indicate the original population of the species from the surroundings of Jędrzejów.

\section{LITERATURE CITED}

BROWICZ T., GOSTYŃSKA-JAKUSZEWSKA M. 1966. Atlas rozmieszczenia drzew i krzewów w Polsce. Cytisus albus (Hacq.) - Szczodrzeniec zmienny, 5. Państwowe Wydawnictwo Naukowe, Poznań, pp. 24. (in Polish)

DZWONKO Z. 2007. Przewodnik do badań fitosocjologicznych. Wydawnictwo Naukowe PWN, Warszawa. (in Polish)

FIJAŁKOWSKI D. 1954. Wykaz rzadszych roślin Lubelszczyzny - Enumeratio plantarum variorum Terre Lublinensis. Fragm.. Flor. Geobot. 1: 81-93. (in Polish)
FIJAŁKOWSKI D. 1957. Zbiorowiska kserotermiczne projektowanego rezerwatu stepowego koło Czumowa nad Bugiem. Ann. UMCS, Sec. C 10: 311-319. (in Polish)

FIJAŁKOWSKI D. 2001. Chamaecytisus albus (Hacq.) Rothm. In: Polska czerwona księga roślin. Paprotniki i rośliny kwiatowe. Kaźmierczakowa R., Zarzycki K. (eds). Inst. Bot. im. W. Szafera PAN, Kraków, pp. 213-214. (in Polish)

GAJEWSKI W. 1937. Elementy flory Polskiego Podola. Planta Polonica, 5:1-211. (in Polish)

HEGI G. 1975. Illustrierte Flora von Mittel-Europa. IV: 3. Verlag Paul Parey, Berlin-Hamburg, p. 1113-1750.

KONDRACKI J. 2002. Geografia Polski. Mezoregiony fizycznogeograficzne. PWN, Warszawa. (in Polish)

KUBÁT K. 2002. Klič ke květně České republiky. Academia, Praha, pp. 928. (in Czech)

MATUSZKIEWICZ W. 2005. Przewodnik do oznaczania zbiorowisk roślinnych Polski. Wydawnictwo Naukowe PWN, Warszawa. (in Polish)

MIREK Z., PIĘKOŚ-MIRKOWA H., ZAJĄC A., ZAJĄC M. 2002. Flowering plants and pteridophytes of Poland - a checklist. In: Mirek Z. (ed.) Biodiversity of Poland 1, W. Szafer Institute of Botany, Polish Academy of Sciences, Kraków, p. 422.

Rozporządzenie Ministra Środowiska z dnia 9 lipca 2004 r. w sprawie gatunków dziko występujących roślin objętych ochroną (Dz. U. z dnia 28 lipca 2004 r).

ZAJĄC A. 1978. Założenia metodyczne "Atlasu rozmieszczenia roślin naczyniowych w Polsce”. Wiad. Bot. 22(3), p. 145-155. (in Polish)

ZARZYCKI K., SZELĄG Z. 2006. Red list of the vascular plants in Poland. Czerwona lista roślin naczyniowych w Polsce. In: Red list of the plants and fungi in Poland. Czerwona lista roślin i grzybów Polski. Mirek Z., Zarzycki K., Wojewoda W., Szelagg Z. (eds). Szafer Institute of Botany, Polish Academy of Sciences, Kraków, pp. 9-20. (in English and Polish) 